Castells E, Morante M, Blanco-Moreno JM, Sans FX, Vilatersana R, Blasco-Moreno A

(2013) Reduced seed predation after invasion supports enemy release in a broad biogeographical survey. Oecologia 173:1397-1409

DOI 10.1007/s00442-013-2718-4

\title{
Reduced seed predation after invasion supports enemy release in a broad biogeographical survey
}

Eva Castells $^{1 *}$, Maria Morante ${ }^{1}$, José M. Blanco-Moreno ${ }^{2}$, F. Xavier Sans ${ }^{2}$, Roser Vilatersana $^{3}$, Anabel Blasco-Moreno ${ }^{4}$

${ }^{1}$ Unitat de Toxicologia, Departament de Farmacologia, Terapèutica i Toxicologia, Facultat de Veterinària, Universitat Autònoma de Barcelona, 08193 Bellaterra, Catalonia (Spain)

${ }^{2}$ Departament de Biologia Vegetal, Facultat de Biologia, Universitat de Barcelona, Avda. Diagonal 643, 08028 Barcelona, Catalonia (Spain)

${ }^{3}$ Botanic Institute of Barcelona (IBB-CSIC-ICUB). Passeig de Migdia s/n, 08038 Barcelona, Catalonia (Spain)

${ }^{4}$ Servei d’Estadística Aplicada, Universitat Autònoma de Barcelona, 08193 Bellaterra, Catalonia (Spain)

*Corresponding author: eva.castells@uab.cat Phone +34 935813833 Fax +34 935812959 
Author contributions: EC conceived the study. EC, JMB, FXS and RV designed the experiments. EC, MM, JMB and RV conducted fieldwork and performed the experiments. ABM and EC analyzed the data. EC wrote the manuscript and other authors provided editorial advice. 
1 Abstract The Enemy Release (ER) hypothesis predicts an increase in the plant invasive

capacity after being released from their associated herbivores or pathogens in their area of origin. Despite the large number of studies on biological invasions addressing this hypothesis, tests evaluating changes in herbivory on native and introduced populations and their effects on plant reproductive potential at a biogeographical level are relatively rare. Here, we tested the ER hypothesis on the South African species Senecio pterophorus (Asteraceae), which is native to the Eastern Cape, has expanded into the Western Cape, and was introduced into Australia (> 70-100 years ago) and Europe (> 30 years ago). Insect seed predation was evaluated to determine whether plants in the introduced areas were released from herbivores compared to plants from the native range. In South Africa, 25\% of the seed heads of sampled plants were damaged. Plants from the introduced populations suffered lower seed predation compared to those from the native populations, as expected under the ER hypothesis, and this release was more pronounced in the region with the most recent introduction (Europe $0.2 \%$ vs. Australia 15\%). The insect communities feeding on S. pterophorus in Australia and Europe differed from those found in South Africa, suggesting that the plants were released from their associated fauna after invasion and later established new associations with local herbivore communities in the novel habitats. Our study is the first to provide strong evidence of enemy release in a biogeographical survey across the entire known distribution of a species.

Key words Enemy Release hypothesis, herbivory, insects, Senecio, reproductive potential 


\section{Introduction}

Biological invasions are one of the major causes affecting biodiversity worldwide (Pimentel et al. 2000). The introduction of an exotic plant into a new habitat can strongly affect the composition, structure and functioning of the invaded ecosystem (Vitousek et al. 1996; Pimentel et al. 2000) and may drive evolutionary changes in the native species (Maron and Vilà 2001; Siemann et al. 2006). Not all species introduced into new habitats become invasive, however (Richards et al. 2006). Of the many hypotheses that attempt to unravel the factors affecting potentially invasive alien species, those involving the role of herbivores in controlling plant populations predominate (Colautti et al. 2004; Hierro et al. 2005; Gurevitch et al. 2011).

The most frequently invoked hypothesis for the success of invasive species is the Enemy Release (ER) hypothesis (Elton 1958). This hypothesis predicts that alien plants will be more successful when colonizing a new environment due to being released from herbivores and pathogens in their area of origin. The ER hypothesis is based on three components (Keane and Crawley 2002): 1) plant populations are regulated by their associated enemies in the indigenous area; 2) herbivore pressure decreases after introduction into a novel range; and 3) the individual-level benefits of enemy release to exotic plants translate into increased population size, geographic distribution, and overall invasive ability. Plants that are strongly regulated by herbivores in their areas of origin can experience immediate benefits after enemy release, with increased growth, reproductive capacity and survival (Colautti et al. 2004).

A decrease in herbivore pressure on exotic plants, as predicted by the ER hypothesis, is not determined exclusively by the plants’ escape from the natural enemies left behind during an invasion. Once in the introduced range, alien plants may be colonized by native herbivores from the novel habitat, a process known as Native Enemy Host Switching (Keane 
and Crawley 2002; Agosta 2006). The diversity of consumers in each novel location limits the types and strengths of the interactions that are ultimately established. For example, Lepidum draba, a herbaceous perennial mustard, is associated with 16 phytophagous species in its native range, 18 in its extended range and 11 in its introduced range; only 4 of these species are common to all three regions (Cripps et al. 2006). When novel interactions as a result of host switching are quantitatively significant, exotic plants may never be released from herbivore pressure but may merely exchange the species involved. The process of enemy release can be understood as the net effect of the loss of associated enemies from the native range and the acquisition of fewer new enemies in the introduced range (Colautti et al. 2004; Verhoeven et al. 2009).

The fact that an important element of the ER hypothesis (i.e., host switching) strongly depends upon the biotic community and the characteristics of the receiver ecosystem (Graves and Shapiro 2003; Tallamy et al. 2010) highlights the importance of studies that account for this geographic mosaic of species assemblages. Commonly performed experiments addressing the ER hypothesis include laboratory bioassays, which determine the preference and performance of selected phytophagous species feeding on plants from the native and introduced ranges (Caño et al. 2008; Schaffner et al. 2011), and common-garden experiments performed in a single area, usually in the invasive range (Agrawal and Kotanen 2003, but see Maron et al. 2004). Although these experiments can help to determine levels of plant resistance against certain herbivores, they do not inform on the actual plant-herbivore interactions established under field conditions. Biogeographical surveys comparing in situ herbivory on native and alien plant populations in areas where the plants naturally occur, are more appropriate to determine realized (not merely potential) herbivore-induced selective pressures. Due to the high spatial variation in the interactions between plants and herbivores 
(Kolb et al. 2007) comprehensive tests of the enemy release hypothesis should cover large distribution areas of the plant species both in the native and the invasive range.

Several authors have stressed the importance of biogeographical comparisons when testing major hypotheses related to biological invasions (Maron and Vilà 2001; Hierro et al. 2005), but this area of research has advanced little in recent years. We found 13 studies published to date that quantified in situ herbivory between native and introduced populations in a replicated biogeographical survey (Sheppard et al. 1996; Memmott et al. 2000; Fenner and Lee 2001; Wolfe 2002; De Walt et al. 2004; Prati and Bossdorf 2004; Vilà et al. 2005; Cripps et al. 2006; Ebeling et al. 2008; Adams et al. 2009; Cripps et al. 2010; Williams et al. 2010; Hinz et al. 2012). Of those, only four (Fenner and Lee 2001; Wolfe 2002; Prati and Bossdorf 2004; Cripps et al. 2010) evaluated seed predation, which is more closely related to plant fitness and population success (Kolb et al. 2007), and none covered a large distributional area across the native and invasive ranges. These numbers contrast markedly with the nearly 500 papers published in the last 10 years that explicitly address the ER and its evolutionary extension the Evolution of increased Competitive Ability (EICA) hypotheses (ISI Web of Science). Clearly, more biogeographical studies of enemy release are needed. Here, we conducted a biogeographical test of the second component of the ER hypothesis using Senecio pterophorus DC (Asteraceae) as a model species. This species is a perennial shrub native to the Eastern Cape and southern KwaZulu-Natal provinces in South Africa (Hilliard 1977). Its range expanded to the Western Cape during the early $20^{\text {th }}$ century (Levyns 1950). Introduced into Australia in 1908, S. pterophorus currently forms persistent populations along the southeastern coast from Port Lincoln to Melbourne and around Sydney and Newcastle in New South Wales (The Council of Heads of Australasian Herbaria 2012). In continental Europe, S. pterophorus was first found in 1982 near Barcelona in the northeastern Iberian Peninsula (Casasayas 1989), and additional populations in the Mediterranean basin 
were found in 1990 on the Ligurian coast in northwestern Italy (Barberis et al. 1998).

Preliminary studies using neutral markers have shown that populations from Australia and Europe are not genetically related; thus the colonization of the two continents occurred independently (Vilatersana et al. unpublished).

We performed a biogeographical survey designed to cover a substantial portion of the distribution of S. pterophorus and to adequately compare seed predation between native and introduced populations. The relatively restricted worldwide distribution of S. pterophorus enabled us to conduct a complete biogeographical survey, determining in situ herbivory on $S$. pterophorus in its native, expanded and invaded ranges. The different colonization histories in Australia ( $>70-100$ years) and Europe ( $>30$ years) and the native vs. expanded ranges in South Africa allowed us to explore the effects of time since introduction and of distance from the source on herbivore release. We aimed to answer the following question: are $S$. pterophorus plants from the extended and introduced ranges released from herbivore predation compared to plants from the native range, resulting in greater reproductive potential?

\section{Materials and methods}

Studied species

Senecio pterophorus is a perennial shrub between 0.4 and $2 \mathrm{~m}$ in height. The capitula, which are up to $1.5 \mathrm{~cm}$ in diameter with c. 13 female ligulate florets measuring from 2 to $4 \mathrm{~mm}$ around the periphery, are grouped into terminal corymbose synflorescences (Hilliard 1977). The seeds (technically achenes or cypselae) are approximately $1.5 \mathrm{~mm}$ long, cylindrical, somewhat angular and minutely hairy over the surface. The flowering period may extend 
from late spring to mid autumn (Levyns 1950) but peaks during two to three weeks in early summer, when all plants in a population bloom synchronously (Morante et al. unpublished).

This species produces a large number of seeds (up to 1200 heads/individual; Morante et al. unpublished), but its population viability is strongly limited by low seedling emergence and establishment (Sans et al. 2004).

Distributional area and invasion history

Senecio pterophorus is indigenous to an area extending from the eastern parts of the Eastern Cape Province to the southernmost part of the KwaZulu-Natal Province (Hilliard 1977) (Fig. 1). In its native range, S. pterophorus forms scattered populations in forest margins, grasslands and fynbos, but it also grows in ruderal habitats, such as road sides. This species was introduced into the Western Cape Province around 1918 (Levyns 1950). The earliest records of S. pterophorus in Australia date to 1908 and 1909 in Melbourne, Victoria, but the absence of herbarium records during the following three decades suggests that the species may have failed to establish successful populations in that area. In 1935, S. pterophorus was found in Port Lincoln, South Australia. From there, it spread to Adelaide Hills and southeast to Melbourne, Victoria, where it reached high levels of infestation during the 1970s (Parsons and Cuthbertson 1992; The Council of Heads of Australasian Herbaria 2012). Scattered populations have been recorded in Sydney and Newcastle, New South Wales, since 1987 (The Council of Heads of Australasian Herbaria 2012) (Fig. 1). In South Australia, S. pterophorus causes heavy productivity losses in agricultural areas, and it is a strong competitor that excludes native species in natural communities and interbreeds with several related native species, thus reducing the diversity of the invaded areas (Parsons and Cuthbertson 1992). In 
1994, S. pterophorus was classified as a Declared Noxious Weed subject to eradication by the Department of Primary Industries, Victoria (Australia).

The first European populations of S. pterophorus were found around wool mills in the United Kingdom in 1913 (Preston et al. 2002), but its presence was erratic and infrequent, with only 8 records from 1913 to 1986 . After being absent from the UK for 30 years, $S$. pterophorus is now considered extinct in that country. The introduction of S. pterophorus into continental Europe is comparatively recent. First recorded in 1982 near Barcelona, northeastern Iberian Peninsula (Casasayas 1989), S. pterophorus is mainly found in disturbed riverbeds and eutrophic waste areas, where it can form very dense populations of approximately 3 individuals $/ \mathrm{m}^{2}$ (Sans et al. 2004). The largest populations occur at the Ripoll River in Sabadell, the most significant textile-manufacturing area in Spain during the $19^{\text {th }}$ and $20^{\text {th }}$ centuries. From 1951 to 1986 , Spanish companies processed 208 metric tons of unwashed wool imported from South Africa and Australia (Dirección General de Aduanas de España 1922), suggesting that S. pterophorus may have been accidentally introduced to Spain via sheep wool used in the textile industry. Since 1995, this species has been widely reported at numerous localities in the northeastern Iberian Peninsula (Chamorro et al. 2006) (Fig. 1). At present, S. pterophorus grows in natural and semi-natural areas, including open forests, road margins and abandoned fields in Sant Llorenç de Munt i l'Obac Natural Park (EC personal observation) and Montseny Natural Park (Morante et al. unpublished). This species has also been found in western Liguria, northwestern Italy, since 1990 (Barberis et al. 1998). The known distribution of S. pterophorus in Italy extends from Savone, $45 \mathrm{~km}$ south of Genova, to Ventimiglia, near the French border (Barberis et al. 1998) (Fig. 1). Although its geographical range in Europe remains limited, S. pterophorus is most likely expanding there, slowly spreading into less-disturbed communities, such as grasslands, shrublands and forests (Chamorro et al. 2006). 
Biogeographical survey

172

173

The survey was planned with two purposes: 1 ) to cover the entire known distribution of $S$. pterophorus, including its native, expanded and introduced ranges; and 2) to target the plants' blooming period to evaluate herbivore damage to reproductive plant parts. Distributional data for S. pterophorus were first obtained from the herbarium records of the South African National Biodiversity Institute, the Australian National Herbarium (Council of Heads of Australasian Herbaria 2012), the Biodiversity Data Bank of Catalonia (Font 2012) and the literature (Hilliard 1977; Barberis et al. 1998; Chamorro et al. 2006; Caño et al. 2008; Morante et al. unpublished). The consulted sources provided contradictory information on the native area of S. pterophorus in South Africa. While Hilliard (1977) stated that the plant "is found in the eastern parts of the Transkei and just enters Natal across its Southern border”, the distribution of S. pterophorus obtained from herbarium records exceeded these limits. Moreover, some records identified as S. pterophorus in the South African National Biodiversity Institute herbarium may correspond to other Senecio species with coincident flowering times and similar morphologies (e.g., S. polyanthemoides Sch. Bip. and S. juniperinus L.f.) (M. Welman, South African National Herbarium in Pretoria, personal communication). To ensure that we covered the entire native range of S. pterophorus we searched outside the limits cited by Hilliard (1977), including the area from Cape Town (Western Cape Province) to Port Elizabeth (Eastern Cape Province) and up to $225 \mathrm{~km}$ north of Durban (KwaZulu-Natal Province). Sampling was conducted during the flowering period of S. pterophorus, in December 2009 and January 2010 in the southern hemisphere (South Africa and Australia) and in July 2010 and July 2011 in the northern hemisphere (Catalonia and Liguria). 

been previously reported. We attempted to choose populations that were spread across the territory, including populations from the distributional limits. We located the species in most

198

of the searched areas (Fig. 1). In South Africa, S. pterophorus was absent from Cape Town to Port Elizabeth (Eastern Cape) and north of Port Shepstone (KwaZulu-Natal), confirming the distribution proposed by Hilliard (1977). The plant was not found in some dry areas in South Australia, including York Peninsula and Murray Bridge. In the State of Victoria, where $S$. pterophorus is declared a noxious weed, the plant was extremely difficult to find, possibly due to the control efforts by local authorities.

A population was defined as a cluster of 15 or more adult individuals. In South Africa and Australia, we chose populations at least $30 \mathrm{~km}$ apart; in Catalonia and Liguria, where the plant is more localized, we choose populations at least $5 \mathrm{~km}$ apart. A total of 50 populations were surveyed, including 14 native (Eastern Cape and KwaZulu-Natal, South Africa), 5 expanded (Western Cape, South Africa) and 31 introduced (13 in Australia and 18 in Europe) (Fig. 1). Of these populations, a total of 48 contained reproductive individuals for which seed predation could be assessed. In each population, we evaluated the habitat type, the sampled patch size, the level of disturbance (low, medium, high), the number of S. pterophorus individuals ( $<25,25-100,100-500$ and $>500$ individuals), the percent cover of $S$. pterophorus (<5\%, 5-25\%, 25-50\%, 50-75\% and 75-100\%) and the percentage of individuals at the seedling stage as an estimate of population recruitment (<1\%, 1-5\%, 5-25\%, 25-50\%, 50-75\% and 75-100\%) (Table 1). Climate data (mean annual temperature and precipitation) for each location were obtained from the WorldClim database (Hijmans et al. 2005) (Table 1). Ten individual plants at reproductive stage were sampled at each population to evaluate herbivore damage. The selected individuals were scattered across the plant patch in order to cover the maximum area of distribution and maximize the distance between 
individuals. A total of 465 plants were surveyed. We collected 20 seed heads from each plant to quantify the proportion damaged by insect herbivores. To ensure homogeneous sampling across populations and regions, ripe seed heads were chosen when possible. Seed heads were dissected on the day of collection by opening them longitudinally through the receptacle, spreading the seeds on a surface, and recording the presence of seed-eating insects therein. A seed head was recorded as "damaged" when predated by phytophagous insects, regardless of their number and developmental stage. We calculated the percentage of damaged heads per individual plant. Insects were raised to adults for identification when possible. Taxonomic identification was performed by Jordi Dantart (Societat Catalana de Lepidopterologia, Spain) (Lepidoptera) and Bernhard Merz (Muséum d'Histoire Naturelle, Switzerland) (Diptera). Other species collected at immature stages (larvae) that were not successfully raised to adults during the collecting trip were classified at the lowest possible taxonomic level. To determine the frequency of predated seeds within capitula, 5 heads from each of 5 individuals per population (8 populations from South Africa, 5 from the Western Cape, 12 from Australia and 12 from Europe) were collected and stored in separate envelopes. Only healthy, ripe heads with no external damage were collected. These samples could not be processed during the collecting trip; therefore, the heads were frozen for $24 \mathrm{~h}$ to prevent further herbivore damage. In the laboratory, the heads were dissected, and the total number of seeds (achenes) was recorded. Each seed was assigned to one of the following categories: damaged, showing signs of predation; aborted, having an undeveloped embryo; and filled, having an undamaged, well-developed embryo. A total of 68,621 achenes (23,610 from South Africa, 21,035 from Australia and 23,976 from Europe) were analyzed. The seeds were categorized by inspection under a stereomicroscope at 10/60 × magnification (Nikon, SMZ800). The proportion of damaged seeds within a head was expressed relative to the total number of achenes after excluding the aborted ones. 
Data analyses

Differences among regions were tested using an ANOVA for continuous variables (altitude, temperature and precipitation) and a likelihood-ratio test for categorical variables (population size, percent cover of S. pterophorus, percentage of seedlings and disturbance level). To evaluate differences among regions in seed-head predation a zero-inflated negative binomial (ZINB) mixed model was calculated considering damage as the response variable, region as a fixed explanatory variable and population as a random factor. We used this type of model due to the large number of zero values in the data (Hall 2000). A ZINB is a mixture model for count data that incorporates two sources of zero values: a negative-binomial distribution for the process generating the counts (NB, seed head damage greater than or equal to 0 ) and a zero-inflation process that separately models the occurrence of extra zero values not accounted for by the process generating the counts (ZI, extra undamaged seed heads). Accordingly, each comparison between regions resulted in two $P$ values, one for the average seed-head damage and one for the zero inflation. Next, a generalized linear model (GLM) was calculated separately for each region to compare the populations therein. A Levene test was conducted to identify differences in the variance across regions.

Differences among regions in the frequency of herbivore-damaged seeds within heads were assessed by a GLMM (generalized linear mixed model). Region and population nested within region were considered fixed factors, and the individual plant was considered a random factor. A negative binomial distribution was used to model the total number of seeds, and a binomial distribution was used to model the percentage of aborted seeds and the percentage of filled seeds. The percentage of damaged seeds was modeled using the variance-transformation proposal of McCullagh and Nelder (1989), which enabled us to control the variability in these 
data. The statistical analyses were performed using SAS System ${ }^{\circledR}$ v9.2 (SAS Institute Inc., Cary, NC, USA). For all statistical tests, a nominal significance level of $5 \%(\mathrm{p}<0.05)$ was applied. A Tukey adjustment was performed for multiple tests.

\section{Results}

Populations of S. pterophorus in the native region (South Africa) were located at a higher altitude (750 m a.s.l.) compared to populations in the extended (133 m) and introduced regions (Australia, 140.7 m; Europe, $192.5 \mathrm{~m}$ ) (South Africa-Western Cape $t=4.19$; South Africa-Australia $t=5.60$; South Africa-Europe $t=5.54 ; P<0.001$ for all pairedcomparisons, ANOVA) (Table 1). Mean annual temperature was significantly higher in the native range in South Africa $\left(16.6^{\circ} \mathrm{C}\right)$ than the introduced ranges in Australia $\left(15.1^{\circ} \mathrm{C}\right)$ and Europe $\left(15.1^{\circ} \mathrm{C}\right)$ (South Africa-Australia $t=3.25, P=0.011$; South Africa-Europe $t=3.52, P$ $=0.005$, ANOVA) but did not differ between the native and extended ranges $\left(16.1^{\circ} \mathrm{C}\right)$ (South Africa-Western Cape $t=0.80, P=0.85$, ANOVA). Mean annual rainfall, $S$. pterophorus population size, percent cover and seedling relative abundance were similar across all four regions (data not shown). Disturbance level differed significantly among regions $\left(\chi^{2}=18.36\right.$, $P=0.005$, likelihood ratio test), with the highest levels found in European populations (Table 1).

Plants in the native range had an average of $25.2 \%$ of their seed heads damaged by herbivores (Fig. 2). In the expanded range, herbivores attacked 33.4\% of the heads per plant, but this value did not differ significantly compared to the native area (NB: $F=1.54, P=$ 0.221; ZI: $F=2.98, P=0.091)$. In Australia, where $S$. pterophorus has coexisted 70-100 years with the native fauna, herbivory levels were lower than in the native area (NB: $F=5.81$, $P=0.020 ; \mathrm{ZI}: F=4.69, P=0.035)$, with an average of $15.4 \%$ of the seed heads damaged 
(Fig. 2). In Europe, where S. pterophorus was introduced more recently compared to Australia ( $>30$ years ago), only $0.2 \%$ of the seed heads per plant were damaged by herbivores, significantly lower than in South Africa (NB: $F=13.43, P=0.001$; ZI: $F=$ 110.62, $P<0.001$ ) or Australia (NB: $F=6.72, P=0.013$; ZI: $F=85.13, P<0.001$ ) (Fig. 2).

Cross-regional comparison of the extra occurrence of zero values (ZI), which indicates the absence of plant-herbivore associations, showed that the South African populations had significantly fewer predation-free seed heads compared to the Australian and European populations. The variances of the frequency of damaged seed heads differed significantly among regions $(F=27.02, P<0.0001$, Levene test). The highest variability, as estimated by the standard deviation (SD), was found in the native and extended ranges $\left(\mathrm{SD}_{\text {South }}\right.$ Africa $=$ 19.73; $\left.\mathrm{SD}_{\text {Western Cape }}=20.03\right)$, followed by the introduced ranges $\left(\mathrm{SD}_{\text {Australia }}=14.96 ; \mathrm{SD}_{\text {Europe }}=\right.$ 1.29).

The number of achenes per head varied across regions, but these differences were not related to the native or invasive status of the populations (Fig. 3a). The seed-predation pattern was similar to the head-predation pattern (Fig. 3b). Plants from the native populations (South Africa) showed significantly higher seed predation compared to plants from the introduced populations (South Africa-Australia $t=14.90, P<0.001$; South Africa-Europe $t=99.94, P<$ 0.001, GLMM) (Fig. 3b). However, in contrast to the results found at the head level, achene predation was higher in the extended range than in the native range (South Africa-Western Cape $t=-3.52, P=0.002$, GLMM). The percentages of aborted and filled seeds varied across regions but showed no pattern related to the native or invasive plant origin (Fig. 3c, d).

The morphology of the collected insects and the analyses of the damage to the heads and seeds showed that the herbivores were similar for plants in the native and expanded ranges but highly distinct in the invaded ranges. In the native and expanded populations in South Africa, the phytophagous insects included monkey beetles (Coleoptera: Scarabeidae, 
Hopliini) and other unidentified Lepidoptera, Diptera and Coleoptera. In Australia, 30.3\% of the predated heads were damaged by Sphenella ruficeps (Macquart 1851) (Diptera: Tephritidae), a species endemic to Australia that is monophagous on Senecio (Hardy and Drew 1996), while an additional $69.6 \%$ of the damaged heads were attacked by various species of microlepidoptera, including members of the family Pyralidae. In Europe, herbivore damage to seed heads was caused exclusively by microlepidoptera belonging to Pyralidae, such as the oligophagous species Phycitodes albatella (Ragonot 1887), which is native to Eurasia and is known to consume three genera within Asteraceae (Senecio, Crepis and Solidago) (Roesler 1973).

\section{Discussion}

Insect seed predation was significantly lower in S. pterophorus growing in its introduced ranges (Australia and Europe) than in plants in the native range (South Africa), as predicted by the ER hypothesis. This pattern was confirmed by two complementary measures of herbivore predation: the frequency of damaged seed heads per plant, and the frequency of damaged achenes within a seed head. Similarly, previous biogeographical studies evaluating differences across native and invaded ranges have mostly supported the ER hypothesis (Memmott et al. 2000; Fenner and Lee 2001; Wolfe 2002; Prati and Bossdorf 2004; De Walt et al. 2004; Vilà et al. 2005; Ebeling et al. 2008; Adams et al. 2009; Cripps et al. 2010) although in some cases this trend was not significant (Sheppard et al. 1996; Cripps et al. 2006; Williams et al. 2010; Hinz et al. 2012). However, the near complete absence of herbivory in some parts of the invaded range, as we found in Europe, has been rarely reported.

We also evaluated herbivory levels on S. pterophorus in an extended distributional area, the Western Cape (South Africa). We considered these populations in a separate 
category because $S$. pterophorus has been introduced recently to that area and thus may exhibit some traits common to cross-continental introductions, even though these populations are relatively close to the area of origin. However, the genetic origin of these populations is unknown, and we cannot ignore the possibility that these plants behave differently from their native counterparts. A recent study analyzing six plant species (Engelkes et al. 2008) has suggested that species whose range is expanding (for example, in response to climate change or habitat availability) will experience reduced herbivory, as expected for enemy release in intercontinental introductions. Contrary to these predictions, predation levels on $S$. pterophorus in the Western Cape were higher than those in the indigenous range, although the difference was significant only for the percentage of damaged achenes and not for the percentage of damaged heads. The relatively small distance between the native range and the extended range may have facilitated the co-introduction of insect species from the native range. Alternatively, if the native insect species have a wider spatial distribution overlapping with the extended range of S. pterophorus, plants in the Western Cape may have had uninterrupted interactions with herbivores, or experience a release from their natural enemies followed by a reassociation in the new environment. Some examples of plants that escaped from herbivory after invasion but later reassociated with their coevolved specialist herbivores in a novel range include Pastinaca sativa in Unites States and New Zealand and Conium maculatum in United States. These species showed high herbivory in the introduced ranges where they had reassociated with their natural enemies (Castells et al. 2005; Zangerl et al. 2008).

Predation levels following an invasion depend upon the balance between the loss of interactions with herbivores native to the area of origin (escape from natural enemies) and the establishment of new interactions with herbivores native to the novel habitat (native-enemy host switching) (Colautti et al. 2004; Verhoeven et al. 2009). Novel associations between non- 
coevolved plants and herbivores are frequent in invaded communities (Keane and Crawley 2002; Graves and Shapiro 2003; Parker and Hay 2005; Tallamy et al. 2010) and therefore may be an important component of plant-herbivore networks in the invaded habitat (Colautti et al. 2004). However, very few studies have compared insect identities and abundance between native and invasive locations in a biogeographical survey (Cripps et al. 2006), and thus the information available to date is not sufficient to determine whether herbivory levels in a novel range are mostly explained by partial escape from associated insects in the indigenous range, by the establishment of new interactions via host switching in the novel habitat, or by a combination of both mechanisms. These different scenarios have no small consequences on the plant evolutionary outcomes as new plant-herbivore associations may alter the herbivore selection regimes, causing plant traits to evolve toward different traits in native and invasive communities (Thompson 1994).

Here, based on taxonomic identifications and the morphology of non-identified insect species in the native and introduced populations, we found that insects present in $S$. pterophorus from Europe and Australia differed from those in South Africa, indicating that plant populations in the two introduced areas escaped from coevolved phytophagous species and established novel interactions with herbivores from the introduced range. Host switching was particularly intense in Australia, the region with a longest invasion history, compared to Europe.

Contrary to the assumption that generalist insects are the main component of host shifting in invaded communities (Keane and Crawley 2002; Hinz et al. 2012), we found that monophagous species participated in a novel interaction. One of the most abundant insect species feeding on S. pterophorus in Australia was the endemic specialist Sphenella rucifeps (Macquart 1851) (Diptera: Tephritidae). This fly, which develops and pupates within seed heads, is monophagous on the genus Senecio and has been reported to consume native 
(Senecio lautus and S. amygdalifolius) and exotic species (S. madagascariensis) in Australia (Hardy and Drew 1996). Specialist herbivores that are adapted to feed on native plants may readily establish interactions with exotic congeners because they share a similar chemical composition that facilitates recognition, selection and resistance (Verhoeven et al. 2009). The presence of other native and introduced Senecio species in Australia may have facilitated host switching by the specialist $S$. rucifeps.

In addition to evaluating changes in herbivory after invasion, our study system also enabled us to test differences in seed predation between two cross-continental introductions with independent invasion histories. Plants in both non-native ranges experienced less herbivory than those in native areas, but this release was more pronounced in European individuals than in Australian individuals. Higher levels of host switching in Australia compared to Europe may be explained by differences in the time since the introduction of $S$. pterophorus. In Australia, this species has coexisted with local fauna for at least 70-100 years, approximately 50 years longer than in Europe. A longer time since introduction may lead to more host shifts because time increases the probability of plant-herbivore encounters and, potentially, the adaptation of local insects to new hosts (Hawkes 2007; Mitchell et al. 2010). For example, invasive populations of Chinese tallow tree (Sapium sebiferum) in the United States were released from herbivores only during the early stages of introduction (Siemann et al. 2006). Similarly, herbivore richness and abundance have been reported to increase with the time since the host-plant introduction, reaching levels similar to those found on native plant species 30 to 200 years following an invasion (Hawkes 2007; Brändle et al. 2008). Our results are consistent with this hypothesis, but we cannot reject the possibility that the higher levels of host switching in Australia compared to Europe were due to other causes, such as the local composition of the biotic community. 
This biogeographical survey was designed to capture the spatial variability of the biotic community naturally encountered by $S$. pterophorus and its effects on the native and introduced populations. Our study is the first to show strong evidence of enemy release in a survey covering most of a species’ distributional area, including two independent areas of introduction. The different patterns of herbivore predation in the two introduced areas are consistent with the longer period of coexistence between S. pterophorus and the local fauna in Australia compared to Europe. Whether the reduction of herbivory on the exotic $S$. pterophorus populations determines a higher invasion success remains undetermined. Increased seed production due to lower herbivore damage is a good estimate of plant fitness, but benefits at the individual level do not necessarily translate into enhanced population recruitment, growth, density and spatial distribution (Kolb et al. 2007). An analysis of the plant population dynamics in the native, expanded and invaded areas accounting for the time since plant introduction is necessary to elucidate the role of enemy release in invasion success.

Acknowledgments We thank the collaborators for providing data and helping during the collecting trips: Dr Jaco Le Roux (Stellenbosch University, South Africa), Christina Potgieter (University of KwaZulu-Natal, South Africa), Dr. Ian Thompson (Royal Botanic Gardens, Melbourne, Australia), Tony Dold (Rhodes University, South Africa) and David Wopula (South Africa). We thank Anna Escolà and Pere Losada for outstanding field and laboratory assistance, Estíbaliz Palma for seed analyses, and Bernhard Merz (Muséum d'Histoire Naturelle, Switzerland) and Jordi Dantart (Catalonia) for identification of insect specimens. MM has a FPI predoctoral fellowship from Ministerio de Ciencia e Innovación (Spain). This research was conducted thanks to the financial support provided to EC by Ministerio de Ciencia e Innovación (Spain) (GCL2008-02421/BOS) and Ministerio de Economía y 
Competitividad (Spain) (GCL2011-29205). XS, EC, JMBM and MM belong to the Agroecosystems Research group funded by Generalitat de Catalunya (Catalonia) (2009

SGR1058). The experiments comply with the current laws of the countries (Spain, Italy, Australia and South Africa) in which the experiments were performed. The permits required for sampling were obtained from the corresponding authorities when necessary.

\section{References}

Adams JM, Fang W, Callaway RM, Cipollini D, Newell E (2009) A cross-continental test of the Enemy Release Hypothesis: leaf herbivory on Acer platanoides (L.) is three times lower in North America than in its native Europe. Biol Invasions 11:1005-1016 doi: 10.1007/s10530-008-9312-4

Agosta SJ (2006) On ecological fitting, plant-insect associations, herbivore host shifts, and host plant selection. Oikos 114:556-565 doi: 10.1111 j.2006.0030-1299.15025.x

Agrawal AA, Kotanen PM (2003) Herbivores and the success of exotic plants: a phylogenetically controlled experiment. Ecol Lett 6:712-715 doi: 10.1046/j.14610248.2003.00498.x

Barberis G, Minuto L, Peccenini S (1998) Senecio grisebachii Baker (Compositae), new to the Italian flora. Webbia 52:201-206

Brändle M, Kuhn I, Klotz S, Belle C, Brandl R (2008) Species richness of herbivores on exotic host plants increases with time since introduction of the host. Diver and Distrib 14:905-912 doi: 10.1111/j.1472-4642.2008.00511.x

Caño L, Escarré J, Fleck I, Blanco-Moreno JM, Sans FX (2008) Increased fitness and plasticity of an invasive species in its introduced range: a study using Senecio pterophorus. J Ecol 96:468-476 doi: 10.1007 s00442-008-1182-z 
Casasayas T (1989) La flora al·lòctona de Catalunya. Catàleg raonat de les plantes vasculars exòtiques que creixen sense cultiu al NE de la Península Ibèrica. Dissertation, Universitat de Barcelona

Castells E, Berhow MA, Vaughn SF, Berenbaum MR (2005) Geographic variation in alkaloid production in Conium maculatum populations experiencing differential herbivory by Agonopterix alstroemeriana. J Chem Ecol 31:1693-1709 doi: 10.1007/s10886-0055921-X

Chamorro L, Caballero B, Blanco-Moreno JM, Caño L, Garcia-Serrano H, Masalles RM, Sans FX (2006) Ecología y distribución de Senecio pterophorus (Compositae) en la Península Ibérica. An Jard Bot Madr 53:55-62 doi: 10.3989/ajbm.2006.v63.i1.31

Colautti RI, Ricciardi A, Grigorovich IA, MacIsaac HJ (2004) Is invasion success explained by the enemy release hypothesis? Ecol Lett 7:721-733 doi: 10.1111/j.14610248.2004.00616.x

Cripps MG, Schwarzlander M, McKenney JL, Hinz HL, Price WJ (2006) Biogeographical comparison of the arthropod herbivore communities associated with Lepidium draba in its native, expanded and introduced ranges. J Biogeogr 33:2107-2119 doi: 10.1111/j.1365-2699.2006.01560.x

Cripps MG, Edwards GR, Bourdôt GW, Saville DJ, Hinz HL, Fowler SV (2010) Enemy release does not increase performance of Cirsium arvense in New Zealand. Plant Ecol 209:123-134

DeWalt SJ, Denslow JS, Ickes K (2004) Natural-enemy releases facilitates habitat expansion of the invasive thropical shrub Clidemia hirta. Ecology 85:471-483

Dirección General de Aduanas de España (1922) Estadística del comercio exterior de España. Ministerio de Hacienda, Madrid 
Ebeling SK, Hensen I, Auge H (2008) The invasive shrub Buddleja davidii performs better in its introduced range. Divers Distrib 14:225-233 doi: 10.1111/j.14724642.2007.00422.x

Elton CS (1958) The Ecology of Invasions by Animals and Plants. Methuen, London

Engelkes T, Morrien E, Verhoeven KJF, Bezemer TM, Biere A, Harvey JA, McIntyre LM, Tamis WLM, van der Putten WH (2008) Successful range-expanding plants experience less above-ground and below-ground enemy impact. Nature 456:946-948 doi: 10.1038/nature07474

Fenner M, Lee WG (2001) Lack of pre-dispersal seed predators in introduced Asteraceae in New Zealand. New Zeal J Ecol 25:95-99

Font X (2012) Vegetation and flora module. Biodiversity database of Catalonia. <http://biodiver.bio.ub.es/biocat/homepage.html>. Accessed 28 November 2012

Graves SD, Shapiro AM (2003) Exotics as host plants of the California butterfly fauna. Biol Conserv 110:413-433 pii: S0006-3207(02)00233-1

Gurevitch J, Fox GA, Wardle GM, Inderjit, Taub D (2011) Emergent insights from the synthesis of conceptual frameworks for biological invasions. Ecol Lett 14:407-418 doi: 10.1111/j.1461-0248.2011.01594.x

Hall DB (2000) Zero-inflated Poisson and binomial regression with random effects: A case study. Biometrics 56:1030-1039 doi: 10.1111 j.0006-341X.2000.01030.x

Hardy DE, Drew RAI (1996) Revision of the Australian Tephritini (Diptera: Tephritidae). Invertebr Taxon 10:213-405 doi: 10.1071/IT9960213

Hawkes CV (2007) Are invaders moving targets? The generality and persistence of advantages in size, reproduction, and enemy release in invasive plant species with time since introduction. Am Nat 170:832-843 doi: 10.1086/522842 
Hierro JL, Maron JL, Callaway RM (2005) A biogeographical approach to plant invasions: the importance of studying exotics in their introduced and native range. $\mathrm{J}$ Ecol 93:5-15 doi: 10.1111/j.1365-2745.2004.00953.x

Hijmans RJ, Cameron SE, Parra JL, Jones PG, Jarvis A (2005) Very high resolution interpolated climate surfaces for global land areas. Int J Climatol 25:1965-1978 doi: 10.1002/joc.1276

Hilliard OM (1977) Compositae in Natal. University of Natal Press, Pietermaritzburg

Hinz HL, Schwarzlander M, McKenney JL, Cripps MG, Harmon B, Price WJ (2012) Biogeographical comparison of the invasive Lepidium draba in its native, expanded and introduced ranges. Biol Invasions 14:1999-2016

Keane RM, Crawley MJ (2002) Exotic plant invasions and the enemy release hypothesis. Trends Ecol Evol 17:164-170 pii: S0169-5347(01)02430-2

Kolb A, Ehrlén J, Eriksson O (2007) Ecological and evolutionary consequences of spatial and temporal variation in pre-dispersal seed predation. Perspect Plant Ecol 9:79-100 doi: 10.1016/j.ppees.2007.09.001

Levyns MR (1950) Compositae. In: Adamson RS, Salter TM (eds) Flora of the Cape Peninsula. Juta \& Co., Cape Town, South Africa, pp 760

Maron JL, Vilà M (2001) When do herbivores affect plant invasion? Evidence for the natural enemies and biotic resistance hypotheses. Oikos 95:361-373 doi: 10.1034/j.16000706.2001.950301.x

Maron JL, Vilà M, Bommarco R, Elmendorf S, Beardsley P (2004) Rapid evolution of an invasive plant. Ecol Monogr 74:261-280

McCullagh P, Nelder JA (1989) Generalized Linear Models. Chapman \& Hall, London 
Memmott J, Fowler SV, Paynter Q, Sheppard AW, Syrett P (2000) The invertebrate fauna on broom, Cytisus scoparius, in two native and two exotic habitats. Acta oecol 21:213222

Mitchell CE, Blumenthal D, Jarosik V, Puckett EE, Pysek P (2010) Controls on pathogen species richness in plants' introduced and native ranges: roles of residence time, range size and host traits. Ecol Lett 13:1525-1535 doi: 10.1111/j.1461-0248.2010.01543.x

Parker JD, Hay ME (2005) Biotic resistance to plant invasions? Native herbivores prefer nonnative plants. Ecol Lett 8:959-967 doi: 10.1111 j.1461-0248.2005.00799.x

Parsons WT, Cuthbertson EG (1992) Noxious weeds of Australia. Inkata Press,

Pimentel D, Lach L, Zuniga R, Morrison D (2000) Environmental and economic costs of nonindigenous species in United States. Bioscience 50:53-65

Prati D, Bossdorf O (2004) A comparison of native and introduced populations of the South African Ragwort Senecio inaequidens DC. in the field. In: Breckle SW, Schweizer B, Fandmeier A (eds) Results of the worldwide ecological studies. Verlag Günther Heimbach, Stuttgart, pp 353-359

Preston CA, Pearman DA, Dines TD (2002) New altlas of the British \& Irish flora: an atlas of the vacular plants of Britain, Ireland, the Isle of Man and the Channel Islands. Oxford University Press, Oxford

Richards CL, Bossdorf O, Muth NZ, Gurevitch J, Pigliucci M (2006) Jack of all trades, master of some? On the role of phenotypic plasticity in plant invasions. Ecol Lett 9:981-993 doi: 10.1111/j.1461-0248.2006.00950.x

Roesler U (1973) Phycitinae. 1. Teilband: Trifine Acrobasina. In: Amsel HG, Gregor F, Reisser H (eds) Microlepidoptera Palaearctica. Georg Fromme \& Co, Wien, 
Sans FX, Garcia-Serrano H, Afán I (2004) Life-history traits of alien and native Senecio species in the Mediterranean region. Acta Oecol 26:167-178 doi:

$$
\text { 10.1016/j.actao.2004.04.001 }
$$

Schaffner U, Ridenour WM, Wolf VC, Basset T, Müller C, Müller-Scharer H, Sutherland S, Lortie JL, Callaway RM (2011) Plant invasions, generalist herbivores, and novel defense weapons. Ecology 92:829-835

Sheppard AW, Brun LA, Lewis RC (1996) A demographic comparison of common heliotrope. Heliotropium europaeum L.: Southern Australia and Southern France. In: Shepherd RCH (ed) Eleventh Australian Weeds Conference Proceedings. Weed Science Society of Victoria, Victoria, pp 286-290

Siemann E, Rogers WE, DeWalt SJ (2006) Rapid adaptation of insect herbivores to an invasive plant. Proc R Soc B-Biol Sci 273:2763-2769 doi: 10.1098/rspb.2006.3644

Tallamy DW, Ballard M, D'Amico V (2010) Can alien plants support generalist insect herbivores? Biol Invasions 12:2285-2292 doi: 10.1007 s10530-009-9639-5

The Council of Heads of Australasian Herbaria (1999) Australia's Virtual Herbarium. <www.chah.gov.au/avh> Accessed 28 November 2012

Thompson JN (1994) The Coevolutionary Process. University of Chicago Press, Chicago

Verhoeven KJF, Biere A, Harvey JA, van der Putten WH (2009) Plant invaders and their novel natural enemies: who is naive? Ecol Lett 12:107-117 doi: 10.1111/j.14610248.2008.01248.x

Vilà M, Maron JL, Marco L (2005) Evidence for the enemy release hypothesis in Hypericum perforatum. Oecologia 142:474-479 doi: 10.1007 s00442-004-1731-z

Vitousek PM, D’Antonio CM, Loope LL, Westbrooks R (1996) Biological invasions as global environmental change. Am Sci 84:468-478 
586 Williams JL, Auge H, Maron JL (2010) Testing hypotheses for exotic plant success: parallel experiments in the native and introduced ranges. Ecology 91:1355-1366

588 Wolfe LM (2002) Why alien invaders succeed: Support for the escape-from-enemy

589 hypothesis. Am Nat 160:705-711 doi: 10.1086/343872

590 Zangerl AR, Stanley MC, Berenbaum MR (2008) Selection for chemical trait remixing in an 591 invasive weed after reassociation with a coevolved specialist. P Natl Acad Sci USA 105:4547-4552 doi: 10.1073/pnas.0710280105 


\section{Figure legends}

Fig. 1 Maps showing locations of populations of S. pterophorus surveyed at the native range (South Africa, populations 6 to 19), the expanded range (South Africa, populations 1 to 5), and the two invasive ranges (Australia and Europe). All populations had reproductive individuals to which damage of herbivores on seed heads and seeds could be evaluated, except for populations 1 and 13 in Australia. Abbreviations for regions or States: in South Africa ECP = Eastern Cape, WCP = Western Cape, KZN = KwaZulu-Natal; in Australia NSW = New South Whales, SA = South Australia, VIC = Victoria; in Europe CAT = Catalonia (Spain), LIG = Liguria (Italy). The shaded area indicates S. pterophorus distribution based on herbaria databases and literature. Population numbers correspond to the codes in Table 1

Fig. 2 Herbivory damage, estimated as the percentage of damaged seed heads among populations from the native (South Africa), expanded (Western Cape, South Africa) and introduced regions (Australia and Europe). Bars represent mean (+ SE, $n=10$ individuals per population). Population codes correspond to numbers given in Figure 1. Inserted graph shows herbivory damage by regions (mean + SE). Different letters indicate significant differences between regions $(P<0.05)$ based on the Zero-Inflation process for ZINB model for count data

Fig. 3 Comparison of seed production and viability in native, expanded and introduced range across regions: a) total number of seeds per head, b) percentage of damaged seeds within a head, c) percentage of aborted seeds, and d) percentage of well-developed, undamaged, filled seeds within a head. Bars represent mean (+SE) for heads within each region ( $n=200$ for 
native South Africa, $\mathrm{n}=125$ for Western Cape, $\mathrm{n}=300$ for Australia and Europe). Different letters indicate significant differences between regions $(P<0.05)$ 
Table 1. Locations and habitat characterization of Senecio pterophorus populations surveyed in the native range (South Africa), the expanded range (Western Cape, South Africa) and introduced ranges (Australia and Europe)

\begin{tabular}{|c|c|c|c|c|c|c|c|c|c|c|c|c|c|c|}
\hline Location $^{1}$ & Population & Code $^{2}$ & Origin $^{3}$ & Coordinates & $\begin{array}{l}\text { Alt. } \\
(\mathrm{m})^{4}\end{array}$ & $\begin{array}{l}\text { Temp. } \\
\left({ }^{\circ} \mathrm{C}\right)^{4}\end{array}$ & $\begin{array}{c}\text { Rainfall } \\
(\mathrm{mm})^{4}\end{array}$ & Habitat type & $\begin{array}{l}\text { Patch size } \\
\text { (m) }\end{array}$ & $\begin{array}{l}\text { Pop. Size } \\
\text { (No. ind.) }\end{array}$ & $\begin{array}{c}\text { SP Cover } \\
(\%)^{5}\end{array}$ & $\begin{array}{c}\text { Seedlings } \\
(\%)^{6}\end{array}$ & $\begin{array}{l}\text { Disturb. } \\
\text { Level }^{7}\end{array}$ & $\begin{array}{c}\text { No. } \\
\text { sampled } \\
\text { ind. }{ }^{8}\end{array}$ \\
\hline \multicolumn{15}{|c|}{ SOUTH AFRICA } \\
\hline ECP & Colchester & S06 & $\mathrm{N}$ & $33^{\circ} 41^{\prime} \mathrm{S} 25^{\circ} 49^{\prime} \mathrm{E}$ & 6 & 16.4 & 440 & Perennial grassland & 50 & $25-100$ & $5-25$ & $1-5$ & $\mathrm{M}$ & 10 \\
\hline ECP & Grahamstown & S07 & $\mathrm{N}$ & $33^{\circ} 19^{\prime} \mathrm{S} 26^{\circ} 32^{\prime} \mathrm{E}$ & 668 & 18.5 & 741 & Meadow & 400 & $>500$ & $5-25$ & $\mathrm{n} / \mathrm{a}$ & M & 10 \\
\hline ECP & Alexandria & S08 & $\mathrm{N}$ & $33^{\circ} 36^{\prime} \mathrm{S} 26^{\circ} 24^{\prime} \mathrm{E}$ & 124 & 16.1 & 548 & Grassland & 10 & $25-100$ & $5-25$ & $<1$ & $\mathrm{M}$ & 10 \\
\hline ECP & Port Alfred & S09 & $\mathrm{N}$ & $33^{\circ} 36^{\prime} \mathrm{S} 26^{\circ} 52^{\prime} \mathrm{E}$ & 61 & 18.2 & 595 & Grassland & 100 & $100-500$ & $25-50$ & $<1$ & $M$ & 10 \\
\hline ECP & Fort Hare & S10 & $\mathrm{N}$ & $32^{\circ} 47^{\prime} \mathrm{S} 26^{\circ} 52^{\prime} \mathrm{E}$ & 535 & 18.2 & 593 & Perennial grassland & 100 & $25-100$ & $25-50$ & $1-5$ & $\mathrm{M}$ & 10 \\
\hline $\mathrm{ECP}$ & Umtentu & $\mathrm{S} 12$ & $\mathrm{~N}$ & $31^{\circ} 51^{\prime} \mathrm{S} 28^{\circ} 30^{\prime} \mathrm{E}$ & 716 & 17.4 & 713 & Meadow & 75 & $25-100$ & $5-25$ & $<1$ & $M$ & 10 \\
\hline ECP & Flargstaff & S13 & $\mathrm{N}$ & $31^{\circ} 11^{\prime} \mathrm{S} 29^{\circ} 26^{\prime} \mathrm{E}$ & 884 & 16.0 & 912 & Meadow & 125 & $>500$ & $50-75$ & $5-25$ & $\mathrm{M}$ & 10 \\
\hline $\mathrm{ECP}$ & Mt. Ayliff & S14 & $\mathrm{N}$ & $30^{\circ} 50^{\prime} \mathrm{S} 29^{\circ} 15^{\prime} \mathrm{E}$ & 1116 & 15.9 & 827 & Meadow & 25 & $>500$ & $50-75$ & $\mathrm{n} / \mathrm{a}$ & $M$ & 10 \\
\hline $\mathrm{ECP}$ & Bizana & S15 & $\mathrm{N}$ & $30^{\circ} 50^{\prime} \mathrm{S} 29^{\circ} 35^{\prime} \mathrm{E}$ & 1076 & 15.6 & 907 & Meadow & 150 & $>500$ & $75-100$ & $\mathrm{n} / \mathrm{a}$ & $M$ & 10 \\
\hline ECP & Mount Frere & $\mathrm{S} 18$ & $\mathrm{~N}$ & $30^{\circ} 57^{\prime} \mathrm{S} 28^{\circ} 57^{\prime} \mathrm{E}$ & 1242 & 15.6 & 856 & Grassland & 35 & $25-100$ & $75-100$ & $<1$ & $\mathrm{H}$ & 10 \\
\hline $\mathrm{ECP}$ & Antioch & S19 & $\mathrm{N}$ & $30^{\circ} 42^{\prime} \mathrm{S} 28^{\circ} 51^{\prime} \mathrm{E}$ & 1261 & 16.0 & 787 & Meadow & 200 & $25-100$ & $5-25$ & $<1$ & $M$ & 10 \\
\hline KZN & Stafford's Post & S16 & $\mathrm{N}$ & $30^{\circ} 31^{\prime} \mathrm{S} 29^{\circ} 46^{\prime} \mathrm{E}$ & 1141 & 15.6 & 927 & Perennial grassland & 10 & $25-100$ & $5-25$ & $\mathrm{n} / \mathrm{a}$ & $\mathrm{M}$ & 10 \\
\hline KZN & Franklin & S17 & $\mathrm{N}$ & $30^{\circ} 23^{\prime} \mathrm{S} 29^{\circ} 38^{\prime} \mathrm{E}$ & 1200 & 15.5 & 834 & Perennial grassland & 50 & $25-100$ & $5-25$ & $1-5$ & $M$ & 10 \\
\hline WCP & Groenfonteinkop & S01 & $E$ & $33^{\circ} 47^{\prime} \mathrm{S} 18^{\circ} 52^{\prime} \mathrm{E}$ & 176 & 16.9 & 786 & Shrubland & 125 & $<25$ & $5-25$ & $1-5$ & $M$ & 10 \\
\hline WCP & Elgin & S03 & $E$ & $34^{\circ} 09^{\prime} \mathrm{S} 19^{\circ} 01^{\prime} \mathrm{E}$ & 326 & 14.7 & 996 & Annual grassland & 200 & $100-500$ & $5-25$ & $<1$ & $\mathrm{H}$ & 10 \\
\hline WCP & Hermanus & S04 & $\mathrm{E}$ & $34^{\circ} 24^{\prime} \mathrm{S} 19^{\circ} 11^{\prime} \mathrm{E}$ & 23 & 16.2 & 589 & Annual grassland & 25 & $100-500$ & $25-50$ & $1-5$ & $\mathrm{M}$ & 10 \\
\hline WCP & Cape Town & S05 & $E$ & $33^{\circ} 56^{\prime} \mathrm{S} 18^{\circ} 26^{\prime} \mathrm{E}$ & 114 & 16.5 & 1086 & Annual grassland & 125 & $100-500$ & $5-25$ & $25-50$ & $\mathrm{H}$ & 10 \\
\hline \multicolumn{15}{|l|}{ AUSTRALIA } \\
\hline NSW & Doonside & A01 & 1 & $33^{\circ} 45^{\prime} \mathrm{S} 150^{\circ} 52^{\prime} \mathrm{E}$ & 48 & 17.2 & 873 & Perennial grassland & 600 & $25-100$ & $5-25$ & $<1$ & $\mathrm{M}$ & 0 \\
\hline NSW & Newcastle & A02 & 1 & $32^{\circ} 52^{\prime} \mathrm{S} 151^{\circ} 41^{\prime} \mathrm{E}$ & 13 & 17.9 & 1092 & Perennial grassland & 50 & $25-100$ & $5-25$ & $1-5$ & $L, M$ & 10 \\
\hline SA & Port Lincoln & $\mathrm{A} 03$ & 1 & $34^{\circ} 33^{\prime} \mathrm{S} 135^{\circ} 49^{\prime} \mathrm{E}$ & 13 & 16.0 & 509 & Perennial grassland & 75 & $>500$ & $50-75$ & $<1$ & M & 10 \\
\hline SA & Wangary & A04 & 1 & $34^{\circ} 30^{\prime} \mathrm{S} 135^{\circ} 25^{\prime} \mathrm{E}$ & 15 & 16.2 & 531 & Annual grassland & 30 & $>500$ & $25-50$ & $<1$ & L & 10 \\
\hline SA & Lincoln NP & A05 & 1 & $34^{\circ} 48^{\prime} \mathrm{S} 135^{\circ} 46^{\prime} \mathrm{E}$ & 6 & 16.2 & 516 & Shrubland & 30 & $>500$ & $5-25$ & $50-75$ & $\mathrm{H}, \mathrm{M}$ & 10 \\
\hline SA & Hincks NP & A06 & I & $33^{\circ} 55^{\prime} \mathrm{S} 136^{\circ} 14^{\prime} \mathrm{E}$ & 84 & 16.4 & 399 & Annual grassland & 4700 & $<25$ & $<5$ & $<1$ & $\mathrm{~L}$ & 7 \\
\hline SA & Mt. Compass & A07 & I & $35^{\circ} 20^{\prime} \mathrm{S} 138^{\circ} 36^{\prime} \mathrm{E}$ & 262 & 14.6 & 801 & Schubland & 30 & $100-500$ & $50-75$ & $50-75$ & $M$ & 10 \\
\hline SA & Cleland NP & A08 & 1 & $34^{\circ} 57^{\prime} \mathrm{S} 138^{\circ} 42^{\prime} \mathrm{E}$ & 602 & 13.0 & 1101 & Forest & 20 & $25-100$ & $<5$ & $5-25$ & $M$ & 10 \\
\hline SA & Warren $\mathrm{CP}$ & A09 & 1 & $34^{\circ} 40^{\prime} \mathrm{S} 138^{\circ} 51^{\prime} \mathrm{E}$ & 257 & 14.9 & 616 & Forest & 25 & $25-100$ & $<5$ & $<1$ & $\mathrm{~L}$ & 10 \\
\hline \multirow[t]{2}{*}{ SA } & Mt. Burr & A10 & 1 & $37^{\circ} 35^{\prime} \mathrm{S} 140^{\circ} 28^{\prime} \mathrm{E}$ & 171 & 13.3 & 867 & Plantation & 30 & $100-500$ & $<5$ & $5-25$ & L & 10 \\
\hline & & & & & & & & & & & & & & 30 \\
\hline
\end{tabular}

Castells et al. (2013) Oecologia 173: 1397-1409 DOI 10.1007/s00442-013-2718-4 


\begin{tabular}{|c|c|c|c|c|c|c|c|c|c|c|c|c|c|c|}
\hline VIC & Mt. Napier NP & A11 & 1 & $37^{\circ} 55^{\prime} \mathrm{S} 142^{\circ} 02^{\prime} \mathrm{E}$ & 223 & 12.9 & 757 & Forest & 15 & $100-500$ & $5-25$ & $75-100$ & $\mathrm{H}$ & 10 \\
\hline VIC & Hastings & A12 & I & $38^{\circ} 17^{\prime} \mathrm{S} 145^{\circ} 11^{\prime} \mathrm{E}$ & 15 & 14.5 & 785 & Shrubland & 15 & $25-100$ & $25-50$ & $<1$ & $\mathrm{H}$ & 2 \\
\hline VIC & Gumbaya Park & A13 & I & $38^{\circ} 04^{\prime} S$ 145039'E & 121 & 13.7 & 960 & Perennial grassland & 10 & $<25$ & $<5$ & $<1$ & M & 0 \\
\hline \multicolumn{15}{|l|}{ EUROPE } \\
\hline CAT & Cambrils & $\mathrm{C} 01$ & 1 & $41^{\circ} 04^{\prime} \mathrm{N} 1^{\circ} 04^{\prime} \mathrm{E}$ & 20 & 16.3 & 549 & River bed & 100 & $25-100$ & $5-25$ & $n / a$ & $\mathrm{H}$ & 10 \\
\hline CAT & Palafolls & $\mathrm{CO} 2$ & I & $41^{\circ} 39^{\prime} \mathrm{N} 2^{\circ} 42^{\prime} \mathrm{E}$ & 66 & 15.6 & 722 & Forest & 75 & $>500$ & $25-50$ & $50-75$ & $\mathrm{H}$ & 10 \\
\hline СAT & Calella & $\mathrm{CO3}$ & I & $41^{\circ} 37^{\prime} \mathrm{N} 2^{\circ} 39^{\prime} \mathrm{E}$ & 144 & 15.6 & 717 & Shrubland & 40 & $>500$ & $75-100$ & $5-25$ & M & 10 \\
\hline СAT & Castellbisbal & $\mathrm{CO4}$ & I & $41^{\circ} 27^{\prime} \mathrm{N} 1^{\circ} 59^{\prime} \mathrm{E}$ & 51 & 16.3 & 589 & River bed & 100 & $25-100$ & $<5$ & $<1$ & $\mathrm{H}$ & 10 \\
\hline СAT & Castellar V. & $\mathrm{C} 05$ & I & $41^{\circ} 36^{\prime} \mathrm{N} 2^{\circ} 04^{\prime} \mathrm{E}$ & 288 & 15.3 & 631 & Annual grassland & 50 & $25-100$ & $5-25$ & $\mathrm{n} / \mathrm{a}$ & M & 10 \\
\hline CAT & Bigues i Riells & $\mathrm{C} 06$ & I & $41^{\circ} 41^{\prime} \mathrm{N} 2^{\circ} 12^{\prime} \mathrm{E}$ & 295 & 15.1 & 667 & Wasteland & 50 & $25-100$ & $50-75$ & $\mathrm{n} / \mathrm{a}$ & $\mathrm{H}$ & 10 \\
\hline CAT & Sabadell & $\mathrm{C} 07$ & I & $41^{\circ} 31^{\prime} \mathrm{N} 2^{\circ} 07^{\prime} \mathrm{E}$ & 124 & 16.1 & 594 & Annual grassland & 30 & $25-100$ & $5-25$ & $5-25$ & $\mathrm{H}$ & 10 \\
\hline САT & Ripollet & $\mathrm{C} 08$ & I & $41^{\circ} 29^{\prime} \mathrm{N} 2^{\circ} 10^{\prime} \mathrm{E}$ & 61 & 16.3 & 599 & Wasteland & 50 & $25-100$ & $<5$ & $<1$ & $\mathrm{H}$ & 10 \\
\hline САТ & Matadepera & Co9 & 1 & $41^{\circ} 35^{\prime} \mathrm{N} 2^{\circ} 01^{\prime} \mathrm{E}$ & 413 & 14.5 & 662 & River bed & 50 & $100-500$ & $25-50$ & $<1$ & M & 10 \\
\hline СAT & Sant Llorenç NP & $\mathrm{C} 10$ & I & $41^{\circ} 36^{\prime} \mathrm{N} 2^{\circ} 05^{\prime} \mathrm{E}$ & 332 & 14.9 & 654 & Grassland, Forest & 30 & $<25$ & $5-25$ & $<1$ & M & 10 \\
\hline CAT & Campins & $\mathrm{C} 11$ & I & $41^{\circ} 43^{\prime} \mathrm{N} 2^{\circ} 28^{\prime} \mathrm{E}$ & 519 & 14.2 & 798 & Forest & 25 & $<25$ & $25-50$ & $\mathrm{n} / \mathrm{a}$ & $\mathrm{L}$ & 10 \\
\hline CAT & Montseny NP & $\mathrm{C} 12$ & 1 & $41^{\circ} 43^{\prime} \mathrm{N} 2^{\circ} 24^{\prime} \mathrm{E}$ & 622 & 13.0 & 822 & Forest & 25 & $25-100$ & $25-50$ & $\mathrm{n} / \mathrm{a}$ & $L$ & 10 \\
\hline LIG & Pietra Ligure & L01 & I & $44^{\circ} 08^{\prime} \mathrm{N} 8^{\circ} 16^{\prime} \mathrm{E}$ & 10 & 14.7 & 846 & Grassland & 100 & $100-500$ & $5-25$ & $1-5$ & $\mathrm{H}$ & 10 \\
\hline LIG & Zucarello & L02 & I & $44^{\circ} 06^{\prime} \mathrm{N} 8^{\circ} 07^{\prime} \mathrm{E}$ & 172 & 14.2 & 807 & Annual grassland & 100 & $25-100$ & $5-25$ & $25-50$ & $\mathrm{H}$ & 10 \\
\hline LIG & Pontedassio & L03 & I & $43^{\circ} 56^{\prime} \mathrm{N} 8^{\circ} 00^{\prime} \mathrm{E}$ & 283 & 14.4 & 794 & Annual grassland & 75 & $100-500$ & $50-75$ & $25-50$ & $\mathrm{H}$ & 10 \\
\hline LIG & Arma di Taggia & L04 & I & $43^{\circ} 50^{\prime} N 7^{\circ} 51^{\prime} \mathrm{E}$ & 14 & 15.7 & 812 & River bed & 500 & $100-500$ & $50-75$ & $<1$ & $\mathrm{H}$ & 10 \\
\hline LIG & Ventimiglia & L05 & I & $43^{\circ} 49^{\prime} \mathrm{N} 7^{\circ} 35^{\prime} \mathrm{E}$ & 21 & 15.7 & 804 & Annual grassland & 80 & $<25$ & $5-25$ & $<1$ & M & 5 \\
\hline LIG & Vado Ligure & L06 & I & $44^{\circ} 16^{\prime} \mathrm{N} 8^{\circ} 25^{\prime} \mathrm{E}$ & 30 & 14.5 & 884 & Annual grassland & 50 & $<25$ & $<5$ & $<1$ & M & 10 \\
\hline
\end{tabular}

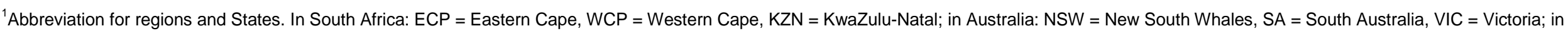
Europe: CAT $=$ Catalonia (Spain), LIG = Liguria (Italy)

${ }^{2}$ Code assigned to each population. Population number corresponds to Fig. 1

${ }^{3}$ Origin: $\mathrm{N}=$ native, $\mathrm{E}=$ expanded, $\mathrm{I}=$ introduced

${ }^{4}$ Altitude, mean annual temperature and mean annual rainfall

${ }^{5}$ Relative cover of $S$. pterophorus in the sampling area

${ }^{6}$ Relative abundance of $S$. pterophorus seedlings in the population, n/a: data not available

${ }^{7}$ Disturbance level: $\mathrm{L}=$ low, $\mathrm{M}=$ medium, $\mathrm{H}=$ high

${ }^{8}$ Number of reproductive individuals that were sampled to assess herbivory on capitula and seeds 
Figure 1

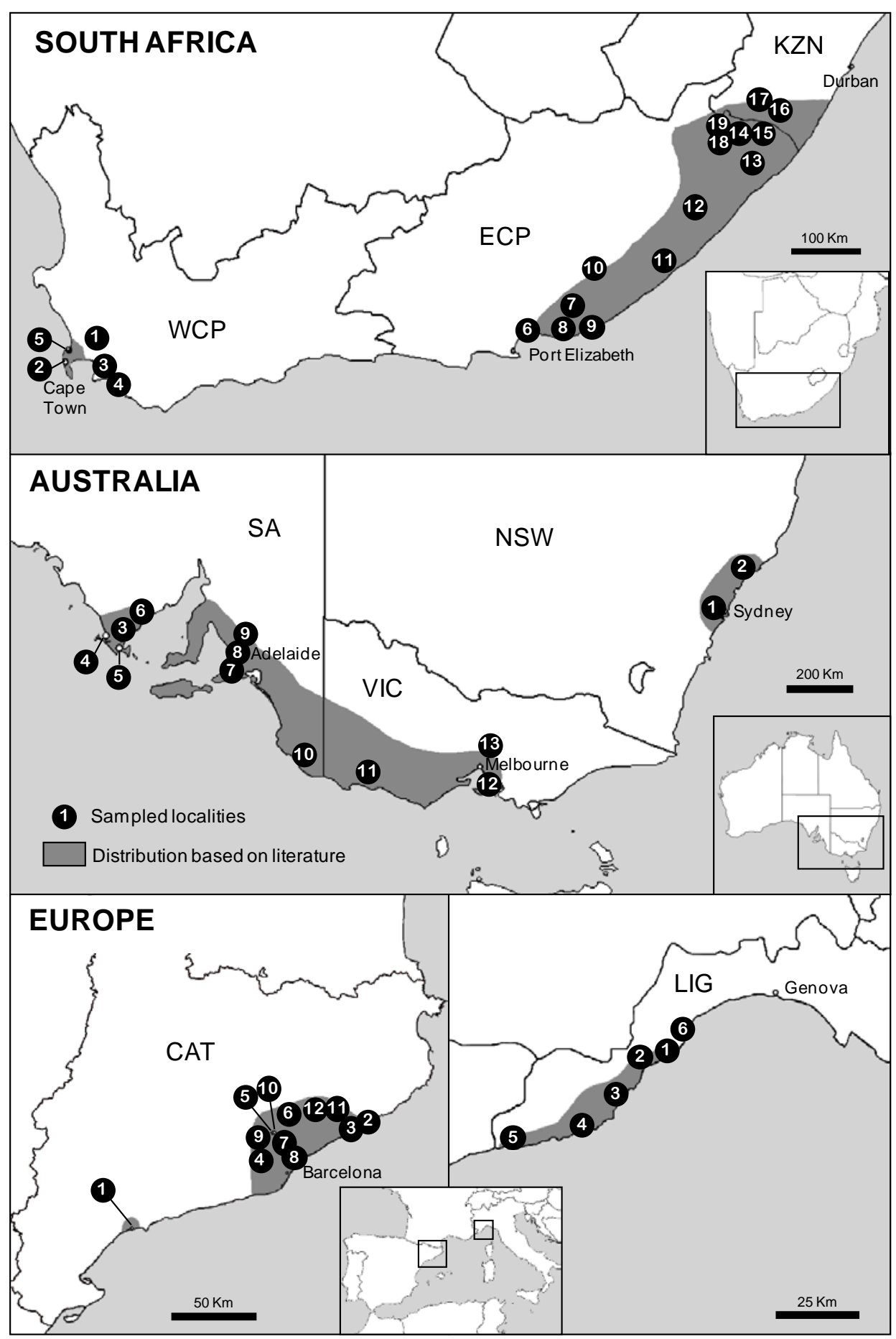


Figure 2

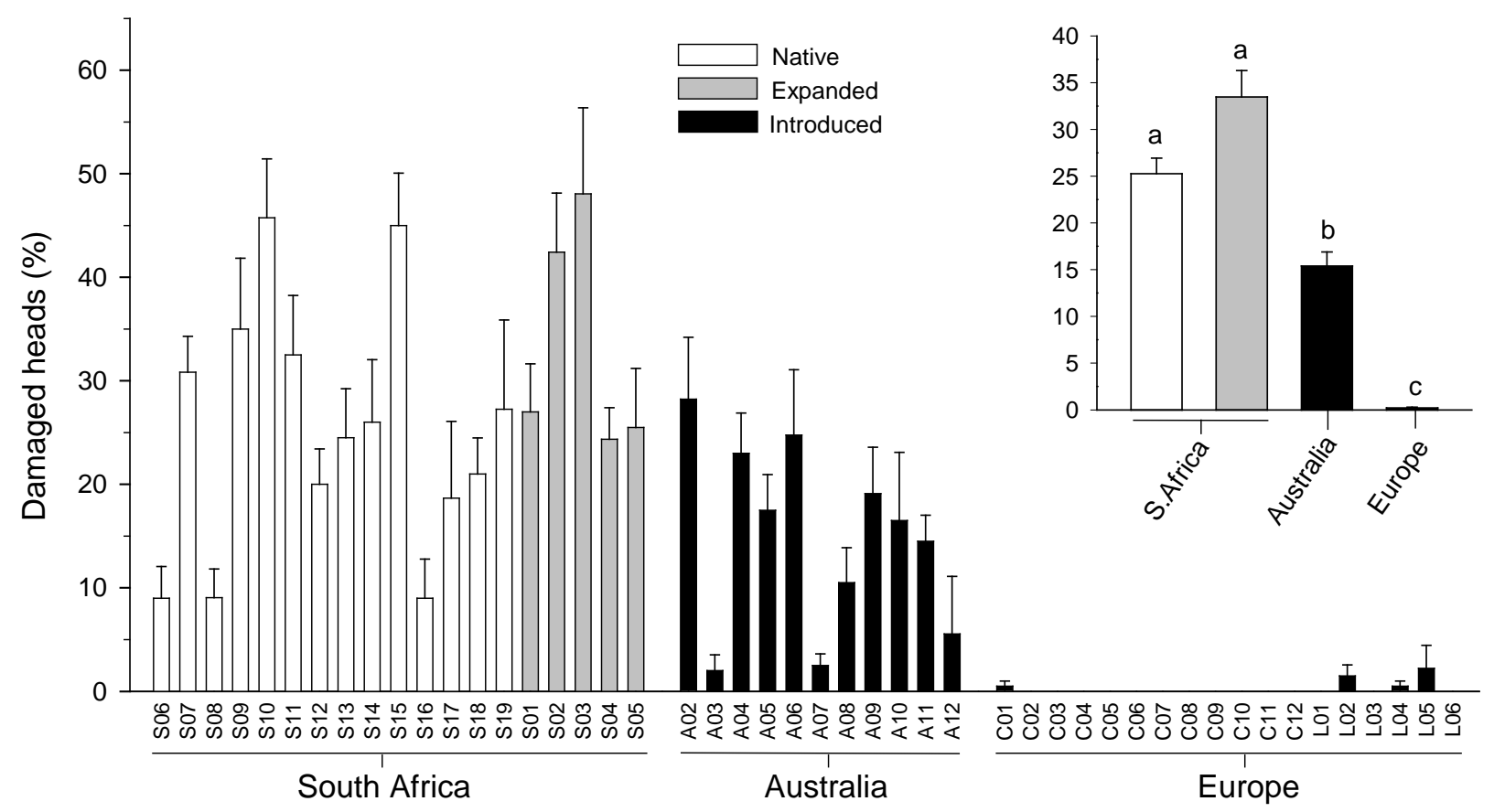


Figure 3
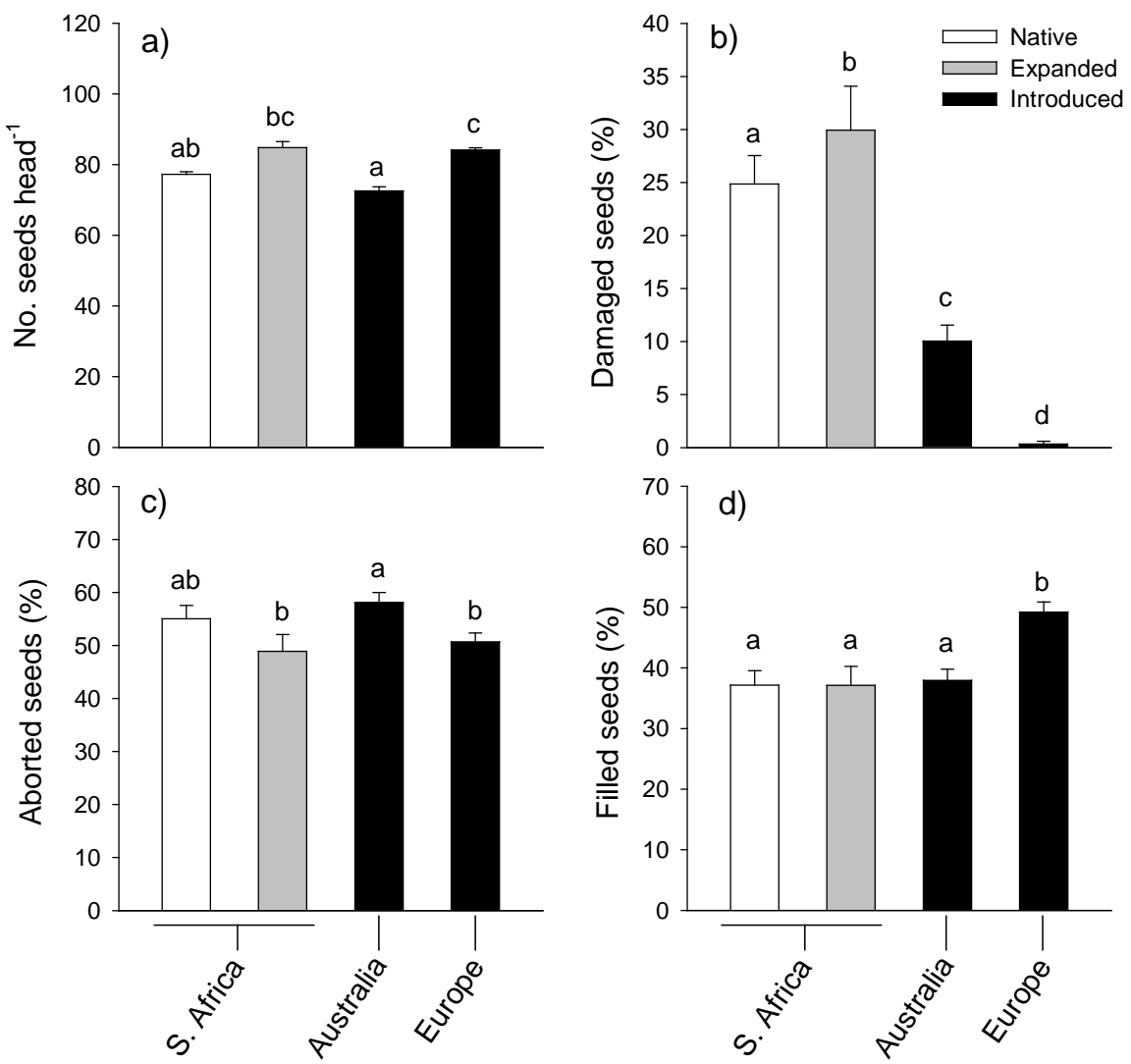